\title{
Performance Analysis of Solar-Assisted Ground-Coupled Heat Pump Systems with Seasonal Thermal Energy Storage to Supply Domestic Hot Water for Campus Buildings in Southern China
}

\author{
Jin Zhou ${ }^{1,2, *}$, Zhikai Cui ${ }^{3}$, Feng $X u^{1,2}$ and Guoqiang Zhang ${ }^{3}$ \\ 1 School of Architecture, Hunan University, Changsha 410082, China; fengxu@hnu.edu.cn \\ 2 Hunan Key Laboratory of Sciences of Urban and Rural Human Settlements in Hills Areas, Hunan University, \\ Changsha 410082, China \\ 3 College of Civil Engineering, Hunan University, Changsha 410082, China; czkai@hnu.edu.cn (Z.C.); \\ gqzhang@hnu.edu.cn (G.Z.) \\ * Correspondence: zhoujin_y@hnu.edu.cn
}

Citation: Zhou, J.; Cui, Z.; Xu, F.; Zhang, G. Performance Analysis of Solar-Assisted Ground-Coupled Heat Pump Systems with Seasonal

Thermal Energy Storage to Supply Domestic Hot Water for Campus Buildings in Southern China. Sustainability 2021, 13, 8344. https:// doi.org/10.3390/su13158344

Academic Editor: Wenye Lin

Received: 5 April 2021

Accepted: 12 June 2021

Published: 27 July 2021

Publisher's Note: MDPI stays neutral with regard to jurisdictional claims in published maps and institutional affiliations.

Copyright: (c) 2021 by the authors. Licensee MDPI, Basel, Switzerland. This article is an open access article distributed under the terms and conditions of the Creative Commons Attribution (CC BY) license (https:// creativecommons.org/licenses/by/ $4.0 /)$.

\begin{abstract}
The supply of domestic hot water (DHW) on college and university campuses is indispensable and is also one of the main components of campus energy consumption. The density of residential patterns and similar occupancy behavior of college students make it economical to use centralized systems to cover the DHW demand, and utilization of solar energy can make the systems more economical. Seasonal thermal energy storage (STES) is a promising key technology that can minimize the imbalance between the availability of solar energy and thermal energy demand. In this paper, a solar-assisted ground-coupled heat pump (SAGCHP) system that meets the DHW demand of 960 students was investigated by means of dynamic simulation and energy-economic analysis. The simulation results in terms of the underground heat balance are compared with a standalone GCHP system and a SAGCHP system without STES. Results show that heat recharging operations during university summer and winter breaks (when there are minimal students on campus) lead to improved underground heat balance and energy performance. Finally, a sensitivity analysis on system performance was carried out by varying solar collector arrays. It was found that there exists an optimal value of solar collector area to achieve the lowest system lifecycle cost (LCC).
\end{abstract}

Keywords: campus DHW demand; solar-assisted ground-coupled heat pump; seasonal thermal energy storage; energy performance; parametric analysis

\section{Introduction}

Continued improvements in standards of living have led to the increasing consumption of energy sources, such as for air conditioning, domestic hot water (DHW) supply and electricity. There is an urgent need to accelerate the development and deployment of advanced clean energy technologies to address the global challenges of energy security, climate change and sustainable development [1]. The education sector, particularly the higher education sector [2], should play increasingly active roles to assist China with achieving a strategic sustainable development plan [3].

During the last two decades, with the rapid development of the higher education sector in China, the demands of student accommodation and corresponding energy requirements have been increasing drastically. As a consequence, campus energy consumption has shown a rapid growth trend, among which the DHW energy consumption accounts for a large portion [4]. Hu [5] conducted a survey on energy consumption of seven college dormitory buildings based on one-year data records obtained from the monitoring platform of a university located in Zhejiang province, China. It was found that DHW energy consumption accounted for $37 \%$ of the total energy consumption. 
In order to reduce the energy consumption of DHW, the use of solar water heaters is becoming an increasingly popular energy choice for college and university dormitory buildings. Solar energy is a pollution-free, inexhaustible and affordable energy resource [6-8]. The utilization of solar energy in centralized hot water systems will enable the systems to be more economically efficient, thereby reducing campus energy consumption and mitigating the greenhouse effect. However, one of the longstanding barriers of utilizing solar energy for DHW purposes is the misalignment between solar energy supply and hot water consumption [9]. Considering the low campus occupancy rate during the summer and winter breaks, this imbalance is exacerbated. Therefore, the energy storage concept is proposed as an essential way to address this mismatching problem between supply and demand [10]. By means of seasonal thermal energy storage (STES) technology, intermittent solar energy harvested and stored during the summer months can be utilized during the winter months when heating demands are high. According to the research of Rad and Fung [11], among several STES technologies, borehole thermal energy storage (BTES) has the most favorable condition for long term energy storage thanks to the large amounts of energy involvement and relatively low cost of storage media.

Since heat loss is inevitable in sensible heat storage across seasons, the temperature of the heat source may not allow the extracted heat to be used directly. Therefore, additional auxiliary equipment, such as heat pumps, need to be installed to raise the temperature level to meet the thermal load requirement [12]. With a solar-assisted system, harvested solar energy is used for ground recharge and for increasing the source fluid temperature entering the heat pump [13]. Borehole recharging features higher soil temperature and shorter length tubes. Heat passing through the evaporator increase the COP of heat pumps, decrease the electricity usage of compressors and reduce operation periods. Trillat [14] proposed different combinations of solar collectors and geothermal heat pumps and identified the best partten from an economical and technical standpoint by numerical simulations using TRNSYS software. The combined solar collectors and geothermal heat pumps helped to reduce the operating costs in comparison with conventional systems using fossil fuels. Rad [15] carried out a study to examine the feasibility of a hybrid ground-coupled heat pump (GCHP) system that used solar thermal collectors as the supplemental component for indoor space heating. It was shown that the solar thermal storage in the ground could reduce the length of the ground heat exchangers tremendously. Zhao [16] developed a mathematical model involving in situ results and economic and technical constraints for a combined thermal solar collector geothermal heat pump system. The optimized length of boreholes and a total area of collectors were calculated based on the model developed. Wang [17] carried out 3D dynamic and numerical simulations for ground heat exchangers in a combined solar collector-geothermal heat pump system. The optimized model was presented after considering the temperature change and heat recovery of the ground. The results indicated that the heat recovery of the ground can increase the reliability of the system while contributing to the economic efficiency of the system. The average soil temperature increased $3{ }^{\circ} \mathrm{C}$ after one year of system operation. Zhai et al. [18] summarized and compared the main integrated approaches of a GCHP system based on available references and their experience. The results showed that the coefficient of performance of different combinations were $3-5$ and that the system combining a geothermal heat pump with thermal solar collectors was the most suitable for heating.

As noted above, the technical feasibility of using BTES to produce DHW has been verified by many engineering practices, but its application for campus DHW preparation still requires special attention [13]. Unlike traditional residential building systems, those on college and university campuses characterize a large fluctuation in occupancy rates depending on the time of year. Correspondingly, DHW demand varies significantly throughout the year, which exacerbates the mismatch between solar energy supply and DHW demand [19,20]. In addition, an investigation [21] showed that there was a large gap between the real DHW usage and the design value for centralized DHW systems currently in China, resulting in system oversizing and inefficient operation. A similar conclusion 
was drawn on the investigation and analysis [22,23] of campus DHW usage in a university of Changsha, China. Furthermore, the huge amount of DHW demand brought by a large number of students in the campus indicates the necessity of a large-scale DHW system, whereas the corresponding large-scale BTES usually takes several years to reach 'design' operating conditions. Therefore, long-term performance assessment is required, which makes the design and performance analysis of BTES systems a considerable challenge.

The aim of this paper is to assess the performance of a solar-assisted ground-coupled heat pump (SAGCHP) system with seasonal thermal energy storage to cover the DHW demand of a group of students, in which the DHW demand data used is derived from research $[24,25]$ based on actual operation records. The main aims of the paper can be summarized as follows:

- Investigate the capability of the proposed system to enhance the exploitation of solar energy to prepare DHW for a typical college dormitory building;

- Evaluate the potential benefits of additional heat storage caused by low occupancy rates during summer and winter vacations;

- Analyze the energy and financial performance from a long-term perspective;

- Explore the influence of the size of solar collector array on the system performance.

In the following sections, the DHW demand of campus building is first described in terms of the number of residents and demand profiles. The proposed SAGCHP, together with the adopted simulation models and the control logic, are then illustrated in detail. Finally, the simulation results are analyzed and discussed.

\section{Analysis Method}

\subsection{Locations and Weather Data}

There are numerous factors that may influence system performance, such as the location, size and efficiency of heat sources (e.g., heat pump, solar collector), operating mode, pipe network structure, insulation thickness of the pipes, hot water usage, and so on. In order to compare the impact of location change on the system performance, different locations were selected for modeling and analyzing in this paper. There are five climate zones in China, i.e., severe cold, cold, hot summer and cold winter, hot summer and warm winter, and mild zones. It should be noted that freezing of circulation fluid in the BHE may occur due to continual heat extraction from the soil with relatively low average temperature. Therefore, the severe cold and cold zones are not included in the present study. Changsha (hot summer and cold winter zone), Guangzhou (hot summer and warm winter zone) and Kunming (mild zone) were selected to represent the other three climate zones of southern China.

Hourly weather data, including global horizontal solar radiation and the ambient temperature of the selected three cities in southern China, including Changsha, Guangzhou and Kunming, were obtained from the Meteonorm software. Figure 1 presents the monthly average ambient temperature $T_{a}$ and the monthly total horizontal irradiance, $I_{h}\left(\mathrm{kWh} / \mathrm{m}^{2}\right)$. As shown in Figure 1, Guangzhou has the highest ambient temperatures (the annual average ambient temperature is $23.0^{\circ} \mathrm{C}$ ), while Kunming has the lowest ambient temperature among the three locations; the annual solar irradiances in Changsha and Guangzhou are relatively close, while the values in Kunming are much higher than the former two cities, reaching up to $1544 \mathrm{kWh} / \mathrm{m}^{2}$. In particular, the maximum solar radiation of Kunming occurred in April, unlike in Changsha and Guangzhou, where the maximum value appeared in July. 


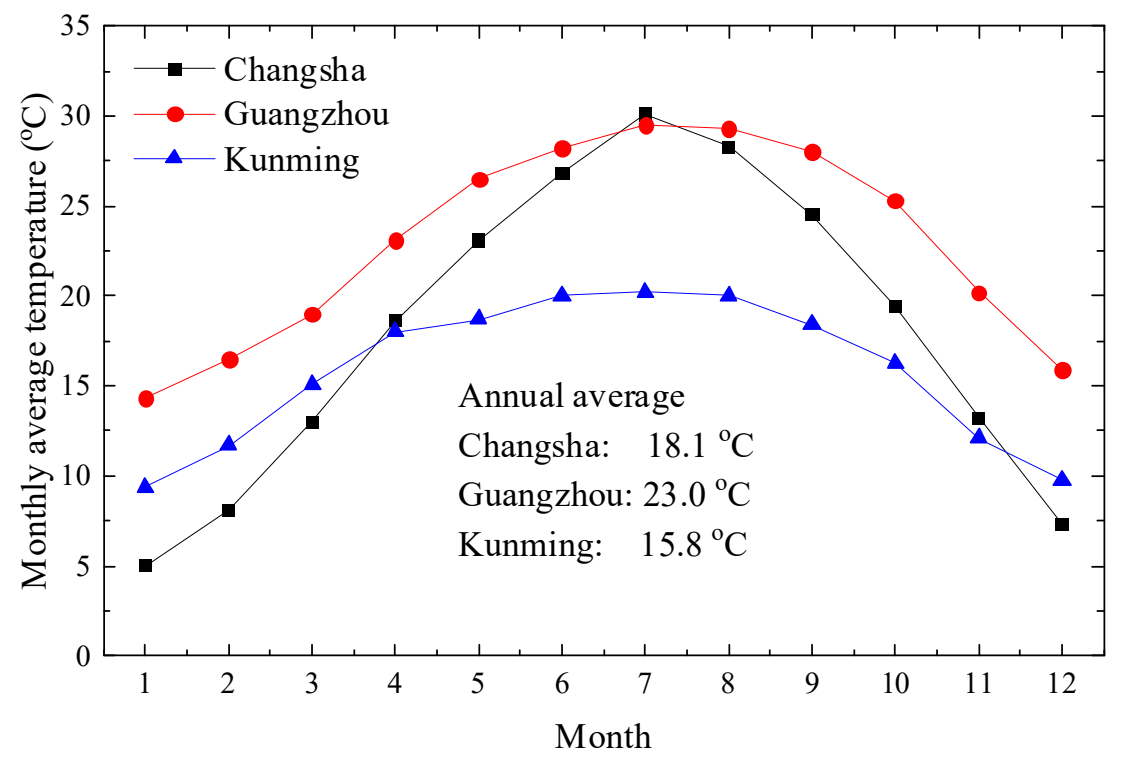

(a)

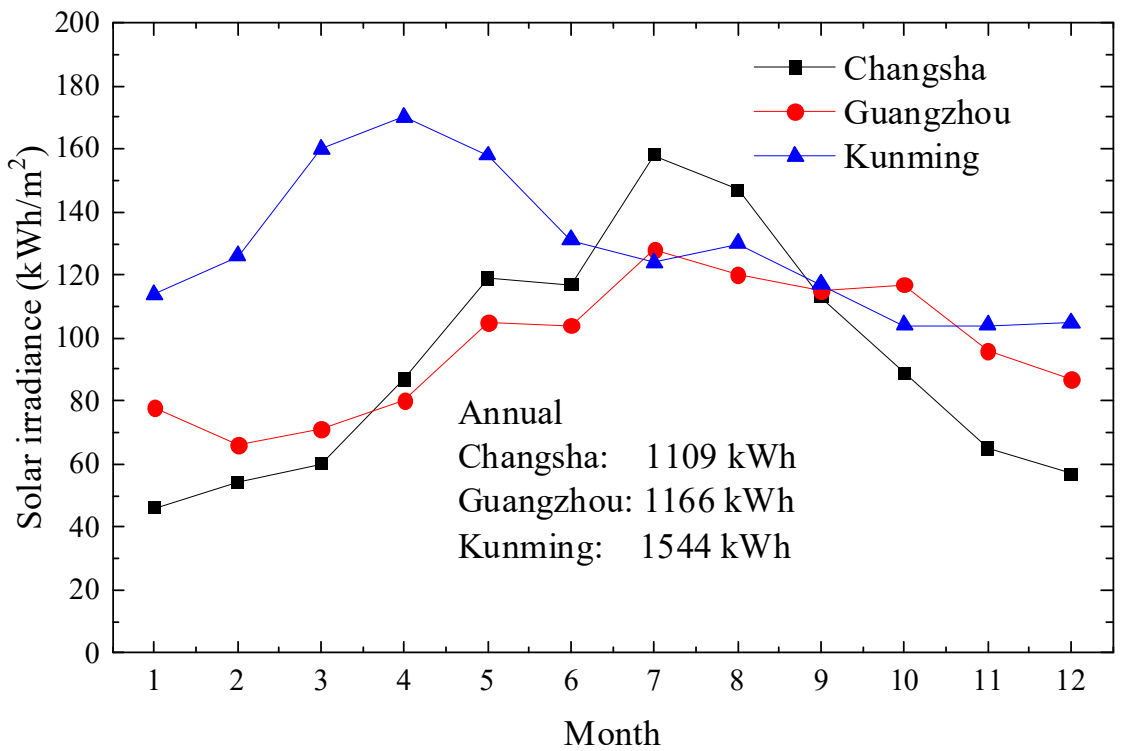

(b)

Figure 1. Weather data of different locations: (a) monthly average temperature and (b) monthly global horizontal solar irradiance.

\subsection{Campus DHW Demand}

The campus DHW system mainly serves the daily demands of students, such as bathing, showering, and washing hands. Different from the demand of occupant groups in ordinary dwellings, the campus occupancy and the corresponding DHW demand may change significantly during the year due to vacations. Especially in China, summer vacation tends to last for two months, which often leads to a low or even zero DHW demand. There exists great mismatch between the low DHW demand and abundant solar resources during this period. Zhou and Yin [23] investigated campus DHW consumption over one year based on the data records of DHW consumption of a college dormitory building located in Changsha, China. It was found that the average daily DHW consumption of male and female students in campus were 23.28 and $24.53 \mathrm{~L} /$ day per occupant, respectively, which are remarkably lower than the recommended value (40-80 L/day) of the design standard used in China [24]. As shown in Figure 2 [23], the daily consumption also varied 
with two peaks, i.e., morning and evening peaks. The morning peaks occurred at 8:00 a.m. and 7:00 a.m. for male and female students, respectively, while evening peaks were found at 23:00 p.m. and 22:00 p.m., respectively.

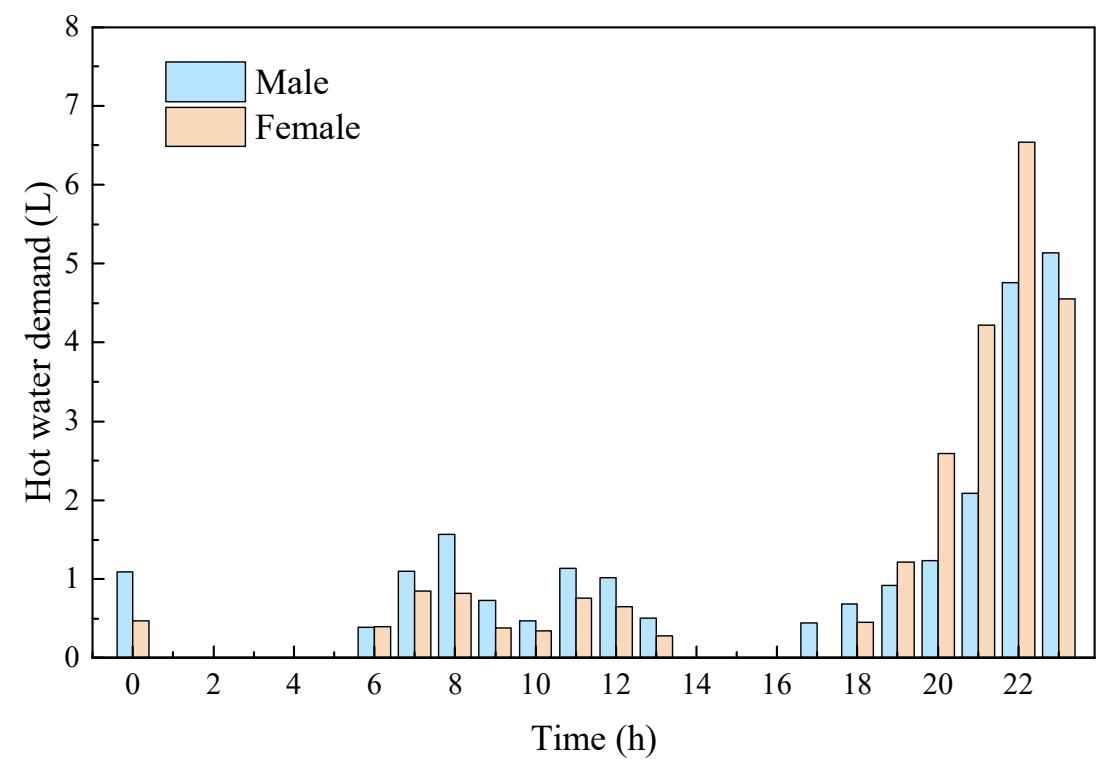

Figure 2. Daily DHW consumption profile.

The campus DHW demand used in this study was determined using the hourly DHW consumption profile shown in Figure 2. To calculate the total DHW demand, the number of students is set to be 960 for a college dormitory building, of which male and female students individually account for a half, i.e., 480. The total daily DHW demand for 960 students was determined to be $22,949 \mathrm{~L} /$ day. The thermal energy needed to match the DHW demand of those 960 students was evaluated with the previous profile and assuming a supply temperature of $45.0^{\circ} \mathrm{C}$, which was determined by the local climate. It is noted that the annual growth of the university population needs to be considered when calculating the entire university's DHW demand.

Each academic year consists of two semesters: spring term from March to June and autumn term from September to January of the following year. The two vacations between these two semesters are known as the Chinese New Year vacation (or winter vacation) and the long summer vacation. Students are usually required to leave college accommodation during these vacations; thus, many students return home or travel, and may undertake paid employment.

During the winter and summer vacations, the campus occupancy and the corresponding DHW demand are relatively low, even falling to zero. In this study, the dates of winter and summer vacations were set as follows: summer vacation from 1 July to 31 August, and winter vacation from 1 February to 31 February, during which the corresponding DHW demand was set to zero. The detail data about campus DHW demand used in this study are summarized in Table 1.

Table 1. Detailed data of DHW demand.

\begin{tabular}{ccc}
\hline Item & Male & Female \\
\hline Population $(\mathrm{P})$ & 480 & 480 \\
Daily water consumption & 23.28 & 24.53 \\
$(\mathrm{~L} / \mathrm{p} \cdot \mathrm{d})$ & & \\
Designed daily water & 22,949 & \\
consumption (L/d) & 1 July-31 August \\
Summer vacation & 1 February-31 February \\
Winter vacation & \multicolumn{2}{c}{} \\
\hline
\end{tabular}




\subsection{System Description and Sizing}

Heat balance is a key issue worthy of attention in the design and operation of a GCHP system. When there is no suitable cooling demand to match the heat demand for producing domestic hot water, the thermal imbalance is more serious than that for a conventional ground-coupled heat pump system.

In order to address the mismatch between solar energy supply and DHW demand, a solar collector system was introduced and combined with the GCHP system. The proposed SAGCHP system provides DHW to campus students during academic time, while the supply of DHW was turned off during summer and winter vacation, and solar energy harvested during that time was used for ground recharging. In particular, Figure 3 presents a simplified system layout and the main components of the SAGCHP system.

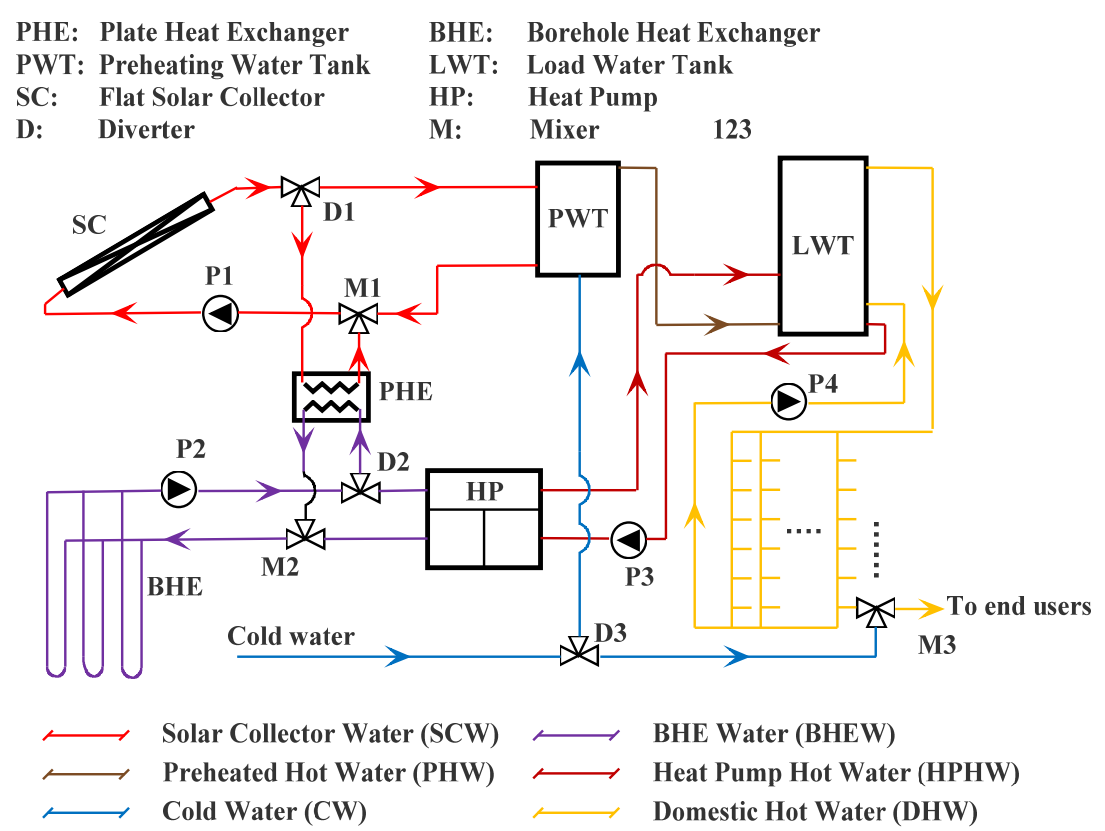

Figure 3. Schematic diagram of the SAGCHP DHW system.

In order to run the system, several closed liquid loops are used, such as solar collector water (SCW), borehole heat exchanger water (BHEW), preheated hot water (PHW), heat pump hot water (HPHW), cold water (CW) and domestic hot water (DHW). It was worth noting that a plate heat exchanger (PHE) is adopted in the system, allowing the heat exchanging between SCW and BHEW. In such configuration, the solar heat can be charged into the borehole when the DHW demand is null in summer and winter vacations to further improve the underground heat balance. However, the adopted scheme implies higher investment/maintenance cost and installation complexity compared to conventional systems. It should be noted that due to the direct water circulation between BHE and HP, there is a potential risk of corrosion within $\mathrm{HP}$, and the common solution is to set up a buffer heat exchanger between BHE and HP. The SAGCHP DHW system in this paper is based on a dormitory building of a university in Changsha, which is not equipped with a buffer heat exchanger, and the SAGCHP DHW system model built as described in this report does not consider a buffer heat exchanger in order to be consistent with the actual situation. However, although the buffer heat exchanger increases the heat transfer loss, it is undeniable that a buffer heat exchanger between BHE and HP is conductive to improving the service life of HP and the operating economy of the system in the long term. 
Only the main system components are indicated in Figure 3, while the other auxiliary components (sensors, controllers, etc.) are omitted for sake of clarity. The operating strategy of the system is stated as follows:

- $\quad$ During academic terms

The SCW is supplied to PWT by switching the flow of D1 to the tank and is pumped from PWT across the solar loop. Specifically, the operation of the circulation pump P1 is controlled by the temperature difference between the solar collector (SC) outlet and PWT bottom. When the temperature difference rises to $8^{\circ} \mathrm{C}$, the control system switches on P1 and supply SCW to PWT until the temperature difference drops to $2^{\circ} \mathrm{C}$.

Tap water is supplied from D3 to PWT, and then is supplied to LWT after receiving heat from the solar loop. During academic terms, if the DHW energy demand is not matched with the thermal energy produced by the solar field, the control system activates P2, P3 and HP, and switches the flow of D2 to BHEW. In particular, the decrease of the middle part temperature of LWT to $50{ }^{\circ} \mathrm{C}$ implies the activation of the GCHP subsystem, until the temperature increases to $55^{\circ} \mathrm{C}$.

The PWT and LWT tank is equipped with a thermostatic valve system (D3/M3) to ensure a stable temperature $\left(45^{\circ} \mathrm{C}\right)$ at the end user-side. From the top of LWT, DHW is supplied to end users through the pipe network according to the supply schedule. Pump P4 operates during the operation time of the pipe network, while it is turned off during the non-DHW supply periods. Finally, the remaining DHW returns to the bottom of LWT. The heat loss of the pipe network system was also considered in this study.

- During winter and summer vacations

During winter and summer vacation, students are usually required to leave college accommodation and the corresponding DHW demand is null. Thus, PWT, LWT, the circulation pump P3 and P4 were switched off during the two long vacations. The control system switches the flow of D1 and D2 to the hot and cold sides of PHE, respectively. The operation of circulation pump P1 and P2 were managed by a control system according to the temperature difference between the outlets of SC and BHE. When the temperature difference rises to $5^{\circ} \mathrm{C}$, the control system switches on P1 and supply SCW to PHE until the temperature difference drops to $2{ }^{\circ} \mathrm{C}$. Through such an operation arrangement, the thermal energy produced in excess by SC is supplied to BHEW and charged into underground soil. The storage solar thermal energy can be utilized during academic terms, thereby alleviating or even eliminating the thermal imbalance.

The sizing of the main components of the proposed SAGCHP system, such as solar collector, storage tank and heat pump, were carried out according to the method and routine based on the prevailing building and engineering practices in the three locations. A summary of the equipment sizing is shown in Table 2.

Table 2. Main components sizing for the proposed SAGCHP system in three selected locations.

\begin{tabular}{cccc}
\hline Component & Changsha & Guangzhou & Kunming \\
\hline Solar collector areas $\left(\mathrm{m}^{2}\right)$ & 338 & 243 & 293 \\
$\begin{array}{c}\text { Capacity of heat pump }(\mathrm{kW}) \\
\text { Storage volume of the } \\
\text { preheating water tank }\left(\mathrm{m}^{3}\right)\end{array}$ & 84 & 63 & 80 \\
$\begin{array}{c}\text { Storage volume of the load } \\
\text { water tank }\left(\mathrm{m}^{3}\right)\end{array}$ & 18.6 & 13.4 & 19.1 \\
\hline
\end{tabular}

\subsection{Simulation Models and Parameters}

The TRaNsient SYStems (TRNSYS) software platform [26] has been used to model and analyze the proposed SAGCHP system. This simulation tool has the capacity to dynamically calculate the energy and mass flows, and temperature profiles for the components in the system. Moreover, the software includes a vast library of built-in components based on validated experimental data. 
In order to perform the proposed system simulation, several component models from the build-in TRNSYS library were adopted, while the other specific models are developed for the control of the system and for the energy and economic analysis.

Flat-plate solar collectors were modeled using TRNSYS Type $1 \mathrm{~b}$ based on the HottelWillier-Bliss approach [27]. In the model, the collector efficiency $\left(\eta_{S C}\right)$ was modeled by a second-order equation (Equation (1)). The coefficients (in SI units) listed in the equations were derived from the manufacturer specifications for a single flat-plate collector (model PGT-2.0, commercialized by the company Jiu Yang [28]):

$$
\eta_{S C}=0.7318-5.86 \frac{\left(T_{S C, \text { in }}-T_{a}\right)}{I}
$$

where $T_{S C, \text { in }}$ is the fluid inlet temperature, ${ }^{\circ} \mathrm{C} ; T_{a}$ is the ambient temperature, ${ }^{\circ} \mathrm{C}$; and $I$ is solar radiation, $\mathrm{W} / \mathrm{m}^{2}$.

TRNSYS Type 557a was adapted to model the borehole heat exchanger (BHE) systems. It is considered to be the state-of-the-art in dynamic simulation of ground heat exchangers that interact thermally with the ground and has been used by several researchers for simulating energy systems with BHE $[29,30]$. The model assumes that the boreholes are placed uniformly within a cylindrical storage volume of the ground; there is convective heat transfer within the pipes and conductive heat transfer to the storage volume.

In this study, TRNSYS Type 534 was used to model the preheating water tank (PWT) and the load water tank (LWT). This type is based on the assumption that the tanks can be divided into $N$ fully mixed equal subvolumes. For each subvolume, the mass and energy balances are considered as a transient state, making it possible to calculate the thermal stratification in the component. In this paper, the PWT and LWT were modeled with 15 isothermal temperature layers to best represent the stratification in the tank, where the top layer is set to 1 and the bottom layer is set to 15 .

The water-water heat pump included in the SAGCHP system was modeled by TRNSYS Type 927. The heat pump performance characteristics considered in the modeling are taken from a heat pump manufacturer and are shown in Figure 4 [31]. This black-box model determines the heat pump effective capacity and its energy consumption by using the water source and sink temperatures as inputs. The information from the manufacturer catalog was used to configure the model, which gives the heat pump performance for inlet source water temperatures $\left(T_{\text {in,source }}\right)$ ranging from -1.1 to $26.7^{\circ} \mathrm{C}$ and for inlet sink water temperatures $\left(T_{i n, \operatorname{sink}}\right)$ ranging from 15.6 to $48.9^{\circ} \mathrm{C}$. It uses a performance map approach that is determined by considering the heat pump heating power and the compressor power, both as a function of the entering source and the sink water temperature. To determine the actual performance of the heat pump, the model interpolates between the values given by the manufacturer. The model does not interpolate beyond the values given by the manufacturer. When the working conditions of source and sink water temperatures are outside the range of the catalog data, the minimum or maximum value is returned by the model.

Moreover, DHW networks are modeled by TRNSYS Type 709 that simulates the thermal behavior of the fluid flow inside the pipe with a model based on variable size axial segments of fluid flow. This model is implemented in order to take into account the dynamic behavior of the district network and to calculate its thermal losses for DHW systems.

The description of the other component models used to perform the simulation is omitted for sake of brevity. The components and corresponding characteristics used in modeling the proposed SAGCHP system are listed in Tables 3 and 4. 


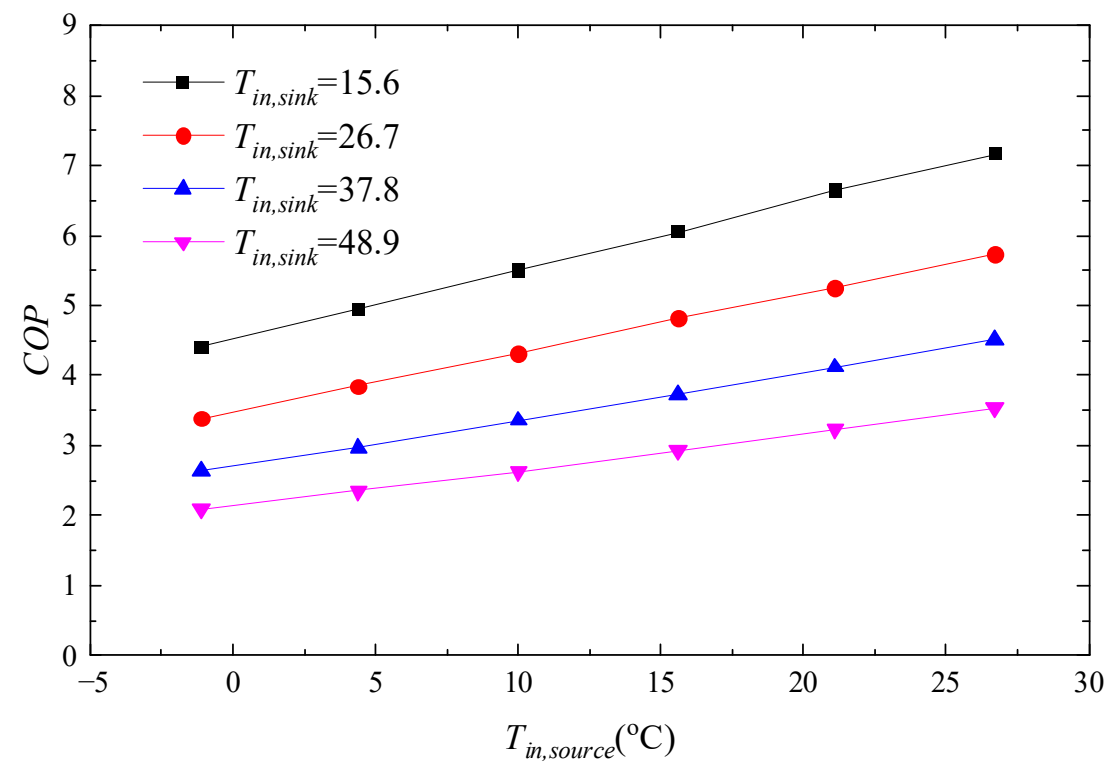

Figure 4. Performance characteristics of the water-water heat pump for different inlet sink and source water temperatures.

Table 3. TRNSYS types used in the proposed system model.

\begin{tabular}{cccc}
\hline Component & Type & Component & Type \\
\hline Flat-plate solar collector & $1 \mathrm{~b}$ & Weather data reader & 15 \\
Water-water heat pump & 927 & On/off controller with & 2 \\
PWT, LWT tank & 534 & hysteresis & 114 \\
Borehole heat exchanger & $557 \mathrm{a}$ & Pump & 11 \\
Plate heat exchanger & 91 & Controller for tempering & 115 \\
Pipes & 709 & valves & \\
\hline
\end{tabular}

Table 4. Main characteristics of the proposed SAGCHP DHW system.

\begin{tabular}{|c|c|}
\hline Component & Characteristic \\
\hline \multicolumn{2}{|l|}{ Plate Solar Collector } \\
\hline Model & PGT-2.0 (commercialized by Jiu yang [28]) \\
\hline Tilted angle & $28^{\circ} 12^{\prime} / 23^{\circ} 08^{\prime} / 25^{\circ} 01^{\prime}$ \\
\hline Orientation & South \\
\hline \multicolumn{2}{|l|}{ Water-to-water heat pump } \\
\hline Model & WHA420 (commercialized by Daikin [31]) \\
\hline Performance data & $\begin{array}{l}\text { Scaled proportionally for the different sizes based on } \\
\text { the model WHA420. }\end{array}$ \\
\hline \multicolumn{2}{|l|}{ Stratified thermal storage tank } \\
\hline Typology & Vertical cylindrical storage tank \\
\hline Heat loss coefficient $\left(\mathrm{W} / \mathrm{m}^{2} \mathrm{~K}\right)$ & 1.39 \\
\hline \multicolumn{2}{|l|}{ Geothermal heat exchanger } \\
\hline Borehole depth (m) & 60 \\
\hline Horizontal Header depth (m) & 1 \\
\hline Borehole radius $(\mathrm{m})$ & 0.055 \\
\hline Soil thermal conductivity (W/m K) & 1.5 \\
\hline Soil heat capacity $\left(\mathrm{kJ} / \mathrm{m}^{3} \mathrm{~K}\right)$ & 2500 \\
\hline Outer radius of the u-tube pipe (m) & 0.01265 \\
\hline Inner radius of the $\mathrm{u}$-tube pipe $(\mathrm{m})$ & 0.01250 \\
\hline Center-to-center half distance (m) & 0.03 \\
\hline Fill thermal conductivity (W/m K) & 1.3 \\
\hline Pipe thermal conductivity (W/m K) & 0.465 \\
\hline
\end{tabular}


Table 4. Cont.

\begin{tabular}{|c|c|}
\hline Component & Characteristic \\
\hline \multicolumn{2}{|l|}{ Plate heat exchanger } \\
\hline Coefficient of heat transfer $\left(\mathrm{kW} / \mathrm{m}^{2} \mathrm{~K}\right)$ & 4.5 \\
\hline Area of heat transfer $\left(\mathrm{m}^{2}\right)$ & 10 \\
\hline \multicolumn{2}{|l|}{ Pump of the solar loop (P1) } \\
\hline Nominal flow rate $(\mathrm{L} / \mathrm{h})$ & $\begin{array}{l}\text { Scaled proportionally to solar collector area }\left(\mathrm{m}^{2}\right) \text {, } \\
\qquad A_{s c} \times 54\end{array}$ \\
\hline Nominal power $(\mathrm{W})$ & Nominal flow rate $/ 10$ \\
\hline \multicolumn{2}{|l|}{ Pump of the source side of GCHP (P2) } \\
\hline Nominal flow rate $(\mathrm{L} / \mathrm{h})$ & $\begin{array}{l}\text { Scaled proportionally to nominal capacity of heat } \\
\text { pump }(\mathrm{kW}), C A P_{h p} \times 160\end{array}$ \\
\hline Nominal power $(\mathrm{W})$ & Nominal flow rate/10 \\
\hline \multicolumn{2}{|l|}{ Pump of the sink side of GCHP (P3) } \\
\hline Nominal flow rate $(\mathrm{L} / \mathrm{h})$ & $\begin{array}{l}\text { Scaled proportionally to nominal capacity of heat } \\
\text { pump (kW), } C A P_{h p} \times 160\end{array}$ \\
\hline Nominal power $(\mathrm{W})$ & Nominal flow rate $/ 10$ \\
\hline \multicolumn{2}{|l|}{ Pump of the DHW distribution (P4) } \\
\hline Nominal flow rate $(\mathrm{L} / \mathrm{h})$ & 1800 \\
\hline Nominal power $(\mathrm{W})$ & 180 \\
\hline \multicolumn{2}{|l|}{ DHW distribution pipework } \\
\hline $\begin{array}{l}\text { Inside diameter of supply, vertical and return pipe } \\
(\mathrm{m})\end{array}$ & $0.053 / 0.02125 / 0.03575$ \\
\hline $\begin{array}{l}\text { Outside diameter of supply, vertical and return pipe } \\
\qquad(\mathrm{m})\end{array}$ & $0.060 / 0.02675 / 0.04225$ \\
\hline Pipe length of supply, vertical and return pipe (m) & $70 / 25 / 190$ \\
\hline Conductive coefficient of pipe (W/m K) & 15 \\
\hline Insulation thickness (m) & $0.035 / 0.030 / 0.030$ \\
\hline Conductive coefficient of insulation layer (W/m K) & 0.0407 \\
\hline Exterior surface coefficient of heat transfer $\left(\mathrm{W} / \mathrm{m}^{2} \mathrm{~K}\right)$ & 11.63 \\
\hline
\end{tabular}

To assess the benefits of STES for system operation, two systems that did not consider seasonal heat storage were introduced for comparative analysis with the original system. To summarize, the differences between all three scenarios are presented in Table 5.

Table 5. Differences between the model's three scenarios.

\begin{tabular}{|c|c|c|c|}
\hline & Description & $\begin{array}{c}\text { System } \\
\text { Configuration }\end{array}$ & Operation Mode \\
\hline Scenario A & SAGCHP system & $\begin{array}{l}\text { Described in } \\
\text { Section } 2.3\end{array}$ & $\begin{array}{l}\text { Described in } \\
\text { Section } 2.3\end{array}$ \\
\hline Scenario B & $\begin{array}{l}\text { SAGCHP system } \\
\text { without soil } \\
\text { recharging }\end{array}$ & $\begin{array}{c}\text { The plate heat } \\
\text { exchanger (PHE) } \\
\text { between BHE and SC } \\
\text { is removed; the other } \\
\text { is the same as } \\
\text { scenario A }\end{array}$ & $\begin{array}{c}\text { Not a soil recharging } \\
\text { operation }\end{array}$ \\
\hline Scenario C & $\begin{array}{c}\text { Standalone GCHP } \\
\text { system }\end{array}$ & $\begin{array}{l}\text { The SC system, } \\
\text { preheat water tank } \\
\text { and PHE are } \\
\text { removed; the other is } \\
\text { the same as scenario } \\
\text { A }\end{array}$ & $\begin{array}{c}\text { No solar-assisted } \\
\text { DHW production and } \\
\text { not a soil recharging } \\
\text { operation }\end{array}$ \\
\hline
\end{tabular}

\subsection{Energy and Economic Performance Indicators}

The system performance was then evaluated through the following indicators:

$$
S P F_{\text {syst }}=\frac{Q_{u}}{W_{p p, t o t}+W_{H P}}
$$




$$
\begin{gathered}
S P F_{h p}=\frac{Q_{u, H P}}{W_{H P}} \\
S F=\frac{Q_{u, S C}}{Q_{u, S C}+Q_{u, H P}}
\end{gathered}
$$

where $S P F_{\text {syst }}$ is the seasonal performance factor of the system; $S P F_{h p}$ is the seasonal performance factor of the heat pump; $S F$ is the solar fraction of the system; $Q_{u}$ is the thermal energy consumed by the end user, in which the heat loss of two storage tanks and the distribution network was subtracted; $Q_{u, H P}$ is the thermal energy produced by HP and supplied to LWT; $Q_{u, S C}$ is the thermal energy produced by SC and supplied to PWT; $W_{p p, t o t}$ is electricity energy consumption of all circulating pumps; and $W_{H P}$ is the electricity energy consumption of HP.

The amount of energy injected in/extracted from the underground STES ( $\left.\eta_{B T E S}\right)$ in different time scales is commonly used to quantify the energy performance of the underground STES $[32,33]$. In addition, storage coefficient $\eta_{B T E S}$ can be calculated to represent the relationship between the extracted heat $Q_{B T E S, \text { extr }}$ and the stored heat $Q_{B T E S, \text { stor }}$ [34]:

$$
\eta_{B T E S}=\frac{Q_{B T E S, \text { extr }}}{Q_{B T E S, \text { stor }}}
$$

where $Q_{B T E S, \text { extr }}$ is the thermal energy extracted from BTES by HP and $Q_{B T E S, \text { stor }}$ is the thermal energy injected and stored in BTES.

Moreover, the average temperature of BTES and its trend over time reflect the state of the underground thermal equilibrium. The difference of average temperature of BTES $\left(\triangle T_{B T E S}\right)$ between the initial $\left(T_{B T E S, a v e, i n i}\right)$ and the end time $\left(T_{B T E S, \text { ave,end }}\right)$ of a 15-year operation can be calculated by Equation (6):

$$
\Delta T_{B T E S}=T_{B T E S, a v e, i n i}-T_{B T E S, \text { ave,end }}
$$

In this paper, the lifecycle cost (LCC) is used to evaluate the cost-effectiveness of the SAGCHP system with solar seasonal thermal storage. The economics model is based on calculations of the present worth of the sum of all costs associated with owning and operating the system over its estimated life. Fundamentally, it is LCC rather than the initial costs or operating costs that dictate the selection of equipment for the hybrid system. The LCC considers the time value of money by relating all future costs to the present costs.

Operation, repair and maintenance costs are calculated for each year during the lifecycle of the system, and it is discounted back to the base date to convert them to the present values. After identifying all costs by year and amount and discounting them to present value, they are added to arrive at total LCC for each alternative, and the present value of the cost of per ton hot water is used to evaluate the economic efficiency of the SAGCHP system. Table 6 presents the financial parameters that must be accounted for in the LCC analysis.

Table 6. Financial parameters used in the LCC analysis.

\begin{tabular}{ccc}
\hline Item & Price & Unit \\
\hline Cost of solar collector & 88.2 & $\mathrm{RMB} / \mathrm{m}^{2}$ \\
Cost of ground-coupled heat pump & 102.9 & $\mathrm{RMB} / \mathrm{kW}$ \\
Cost of the storage tank & 147.1 & $\mathrm{RMB} / \mathrm{m}^{3}$ \\
Cost of the circulating water pump & 73.5 & $\mathrm{RMB} / \mathrm{kW}$ \\
Cost of the plate heat exchanger & 38.2 & $\mathrm{RMB} / \mathrm{m}^{2}$ \\
Borehole drilling & 11.8 & $\mathrm{RMB} / \mathrm{m}$ \\
Price of electricity & 0.151 & $\mathrm{RMB} / \mathrm{kWh}$ \\
Price of water & 0.600 & $\mathrm{RMB} / \mathrm{ton}$ \\
Cost of system installation & $15 \%$ of system initial cost & $\mathrm{RMB}$ \\
Maintenance cost (¥/year) & $1 \%$ of the total initial cost & $\mathrm{RMB} /$ year \\
of maintenance personnel (¥/year) & 7350 & $\mathrm{RMB} /$ year \\
Interest rate & 5 & $\%$ \\
Lifecycle & 15 & year \\
\hline
\end{tabular}




\section{Results and Analysis}

\subsection{Underground Heat Balance}

For the GCHP system without compensation of cooling demand, such as the heat is solely used for DHW production, the heating loads of the GCHP system are unbalanced. Combining the solar collection subsystem with the GCHP system has two aims: (a) reduce the heat provided by the heat pump and the corresponding energy consumption, and (b) compensate the heat imbalance through the injection of solar heat into BTES in summer and winter vacations. In order to verify its validity and sustainability, long-term performance analysis of the SAGCHP system (Scenario A) was conducted and compared with the systems without soil recharging operation (Scenario B) and a standalone GCHP system (Scenario C).

Figure 5 shows the effect of seasonally variable energy extraction and injection for the SAGCHP system in three locations, resulting in undulating trends of the average ground temperatures. It can be observed that the average soil temperatures in Changsha and Guangzhou show an annual fluctuation around the initial temperature of each year and decrease during the long-term operation of 15 years, whereas it increases in Kunming. The reasons for this opposite trend are that, in Changsha and Guangzhou, the extracted energy is not fully replenished and heat conduction in the ground is not sufficient to compensate for the induced deficits. Extra heat stored in underground soil derived from the relative abundant solar radiation in Kunming explains the long-term rising trend of the average soil temperature. In addition, a smaller range of fluctuation in Kunming can also be observed because the heat injected to soil exceeds heat extraction from soil.

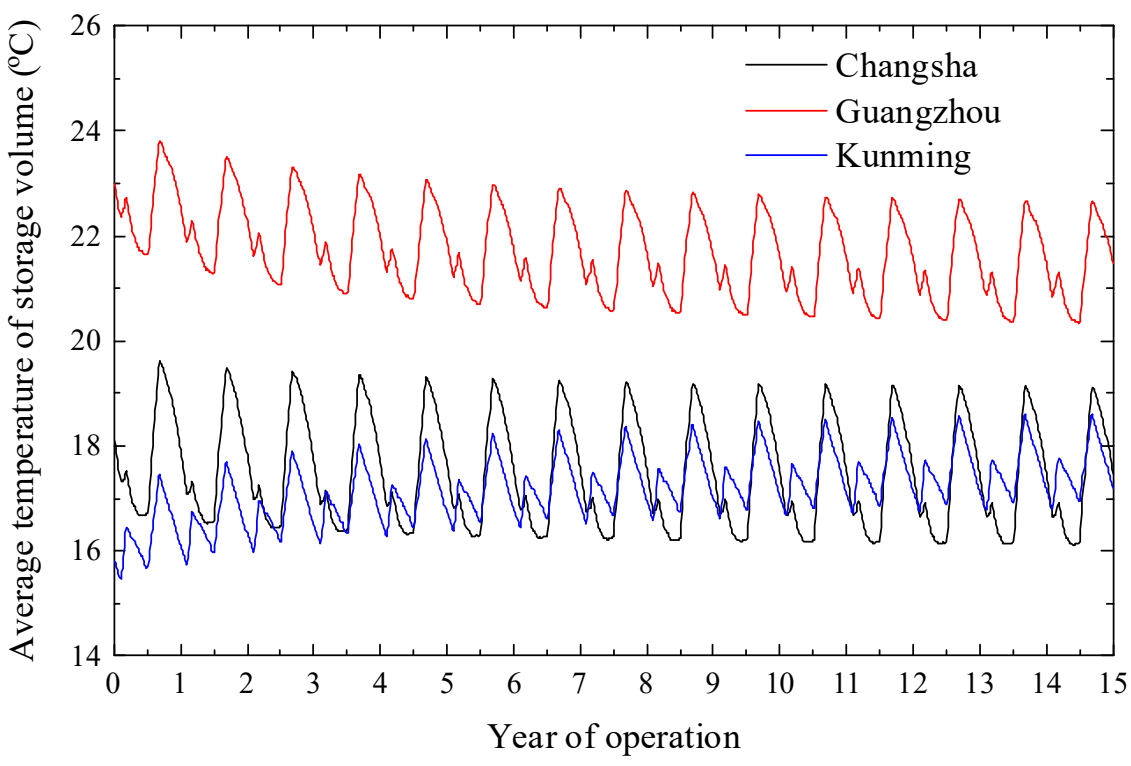

Figure 5. The average soil temperatures for the SAGCHP system in three locations.

The seasonal thermal energy storage in the SAGCHP system is achieved by SC absorbing solar radiation and channeling the heat into the ground, and the amount of heat stored is determined by the intensity of solar radiation and the design of SC. Therefore, in the engineering application of the SAGCHP system, the ground thermal imbalance can be simulated according to TRNSYS software, and the reasonable SC type and solar collector area can be designed according to the thermal gap.

To better understand how the improvement of heat balance is achieved by introducing STES into the GCHP system, Figure 6 shows the comparison of the average annual ground temperature among the three scenarios in Changsha, and Figure 7 shows the comparison of the average monthly ground temperatures in the first year among the three scenarios in Changsha. Due to the largest amount of heat extraction from BHE without compensation 
of soil recharging, the average soil temperature of scenario $C$ has the largest drop among the three scenarios, dropping below $5^{\circ} \mathrm{C}$ after 15 years of operation. Figure 6 shows that the sequence of temperature drop in descending order for the three scenarios is $C$, $\mathrm{B}$ and $\mathrm{A}$. The sharp decline of average ground temperature is caused by the imbalance between ground heat output and input. As shown in Figure 7, during academic terms, the ground-coupled heat pump extracts underground heat to supply DHW in scenario C, so the ground temperature drops sharply, by $1.65{ }^{\circ} \mathrm{C}$ from 1 March to 31 June and by $1.85{ }^{\circ} \mathrm{C}$ from 1 September to 31 December. In scenarios B and A, ground-coupled heat pumps and solar collectors act simultaneously to produce DHW, so the ground temperature drops more gently than that in scenario $\mathrm{C}$. Although solar radiation brings additional heat to the ground in winter and summer vacations, it is difficult to cover the thermal gap, and the temperature rise is limited in scenarios B and C, which is shown in 1 February to 31 February and 1 July to 31 August in Figure 7. However, in Scenario A, by means of STES technology, the thermal imbalance of the ground is covered by efficient solar energy collection and storage during winter and summer vacations, and the soil temperature increases by $3{ }^{\circ} \mathrm{C}$ from 1 July to 31 August, so that the soil temperature remains essentially constant in the long run.

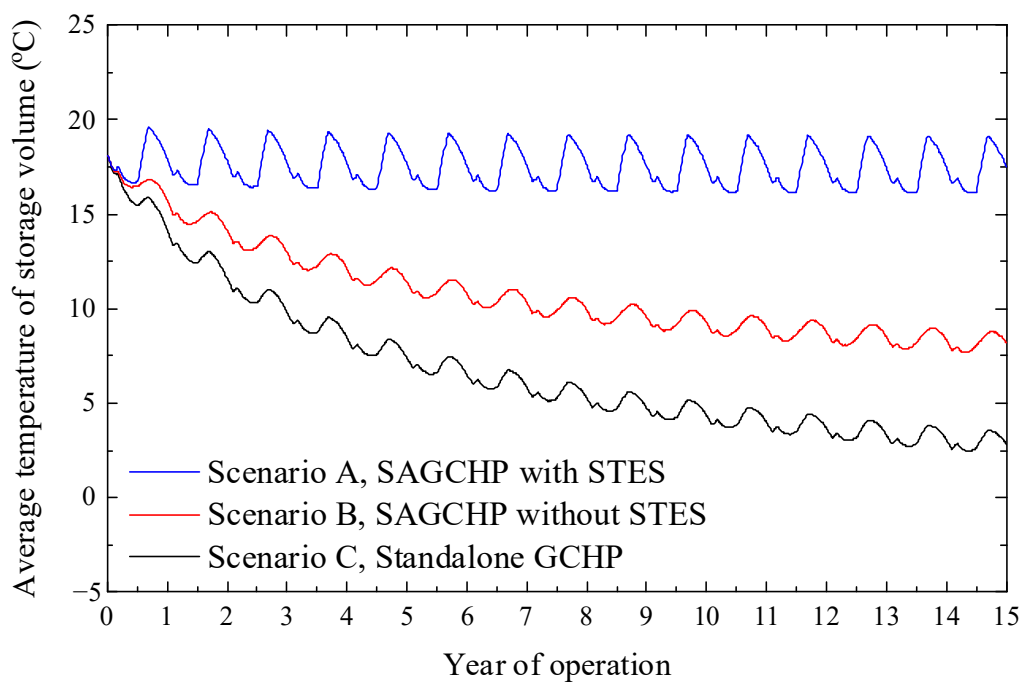

Figure 6. The variation of average annual soil temperature for the three scenarios in Changsha.

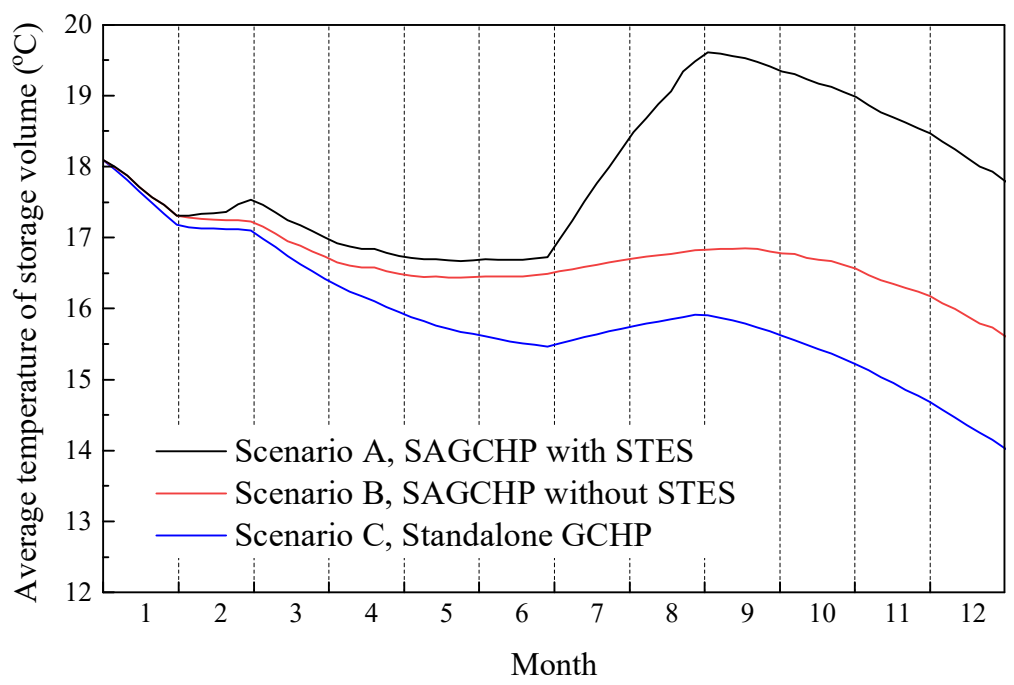

Figure 7. The variation monthly average soil temperature in the first year under the three scenarios in Changsha. 
In addition to the average ground temperature, the variation of inlet and outlet source temperatures of the heat pump is of interest, because it directly influences the operating performance of the heat pump. Figures 8-10 present the results of the inlet and outlet temperatures of the heat pump, and the corresponding $S P F_{h p}$ for scenario A, B and C, respectively.

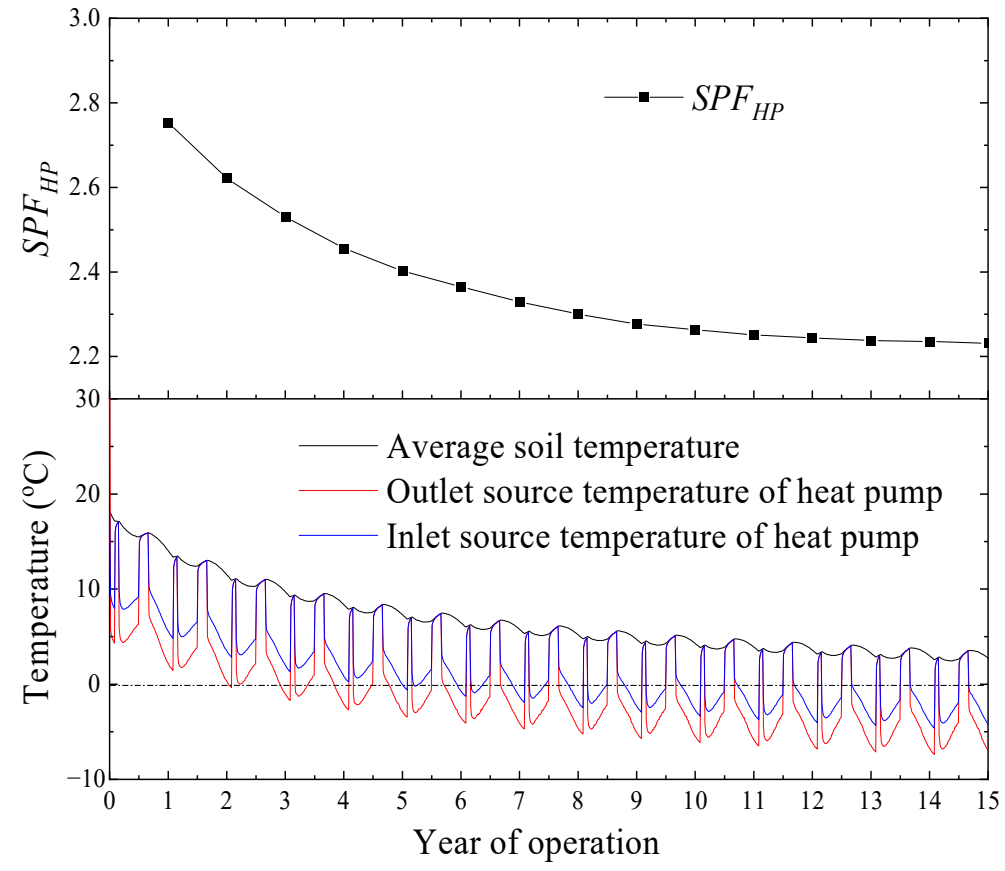

Figure 8. The average soil temperature and the inlet and outlet source temperatures of the heat pump for scenario $\mathrm{C}$ in Changsha.

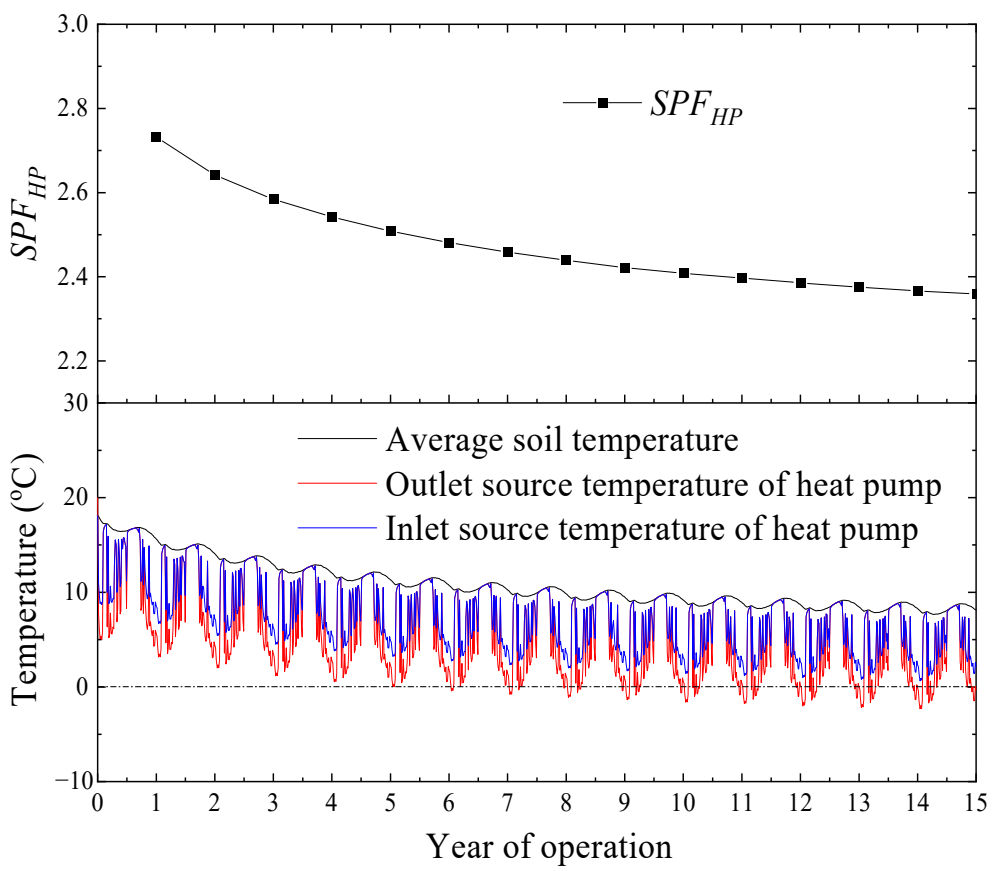

Figure 9. The average soil temperature and the inlet and outlet source temperatures of the heat pump for scenario B in Changsha. 


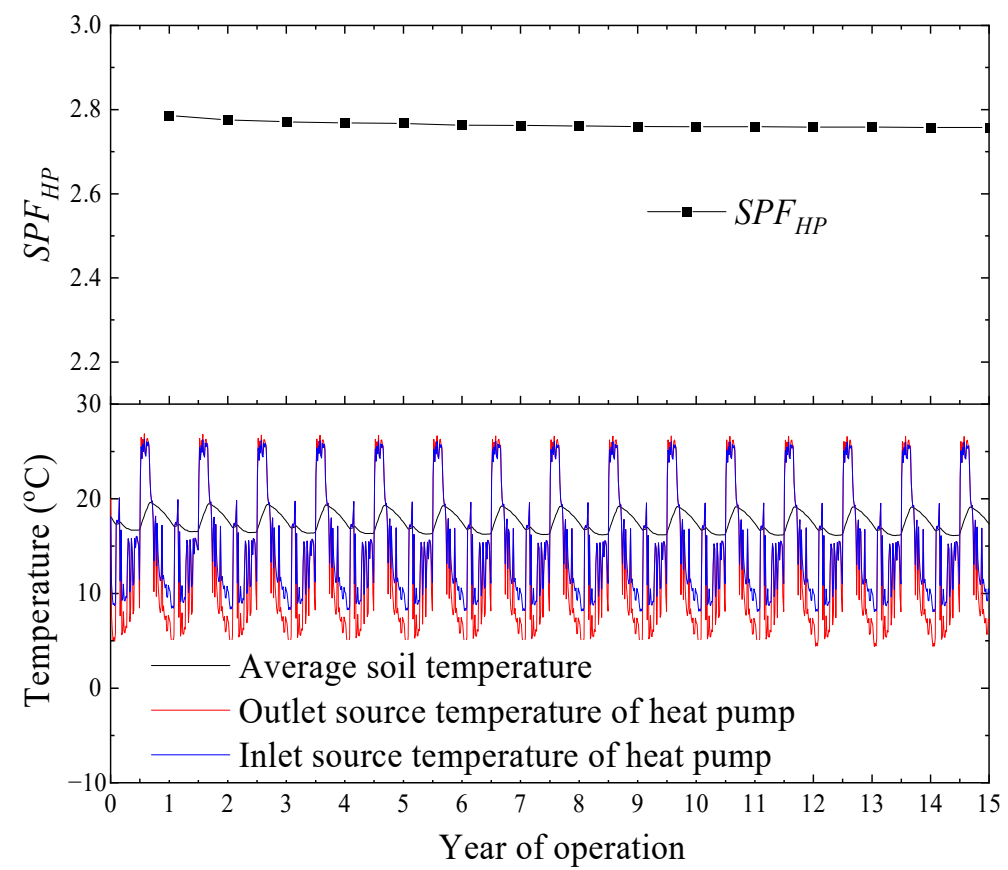

Figure 10. The average soil temperature and the inlet and outlet source temperatures of the heat pump for scenario A in Changsha.

Without the heat compensation of solar heat injection during summer and winter vacations, the outlet temperature of the heat pump evaporator drops to near or below $0{ }^{\circ} \mathrm{C}$ within 3 and 5 years for scenarios $\mathrm{C}$ and $\mathrm{B}$, respectively. The heat pump efficiency, $S P F_{H P}$, declined in the continuous operation mode in both Figures 8 and 9 . This is because long-term heat extraction from the ground soil lowers the average soil temperature around the $\mathrm{BHE}$ and in turn reduces the inlet source temperature to the heat pump. On the contrary, the yearly minimum inlet and outlet temperatures of the heat pump for scenario A remains more than about $7{ }^{\circ} \mathrm{C}$ and $4{ }^{\circ} \mathrm{C}$ due to the soil recharging and the solar-assisted heating process. At the same time, the yearly performance efficiency of the heat pump is relative stable, which is still higher than 2.75 at the end of simulation. Usually, the inlet temperature to the evaporator of the heat pump should be over $6{ }^{\circ} \mathrm{C}$ for pure water heat transfer fluid to protect the system from freezing, assuming a possible temperature drop of $5{ }^{\circ} \mathrm{C}$ during the evaporation process [13]. For scenarios B and C, even without regarding the deterioration of the long-term performance of the heat pump, the antifreeze measures of the underground circulating fluid must be considered.

Compared to Scenarios C and B, the SAGCHP system with STES can effectively solve the heat imbalance problem in the GCHP system, and the HP has better operational performance in this system, so this system is attractive for application to generate DHW for the campus.

\subsection{Energy and Financial Performance}

The performance results of the SAGCHP system during the 15-year operation are presented in Table 7 and Figure 11. The system performance presents substantial enhancement, showing the SPF of 2.788, 3.006 and 4.764 for Changsha, Guangzhou, and Kunming, respectively, while a relatively close $S P F_{H P}$ can also be observed in Table 7 . It is important to notice that the highest $S P F_{\text {syst }}$ in Kunming, among the three locations, is closely related to the richness of local solar resource. The highest value of annual solar radiation (1544 $\mathrm{kWh} / \mathrm{m}^{2}$ ) means that more solar heat can be collected and directly supplied for DHW demand in Kunming, as shown in Figure 11. Meanwhile, in Table 7, $\eta_{\text {BTES }}$ shows an opposite trend to SF. As the solar radiation intensity increases, the heat stored by SC to the ground grows, so the value of $\eta_{B T E S}$ decreases. 


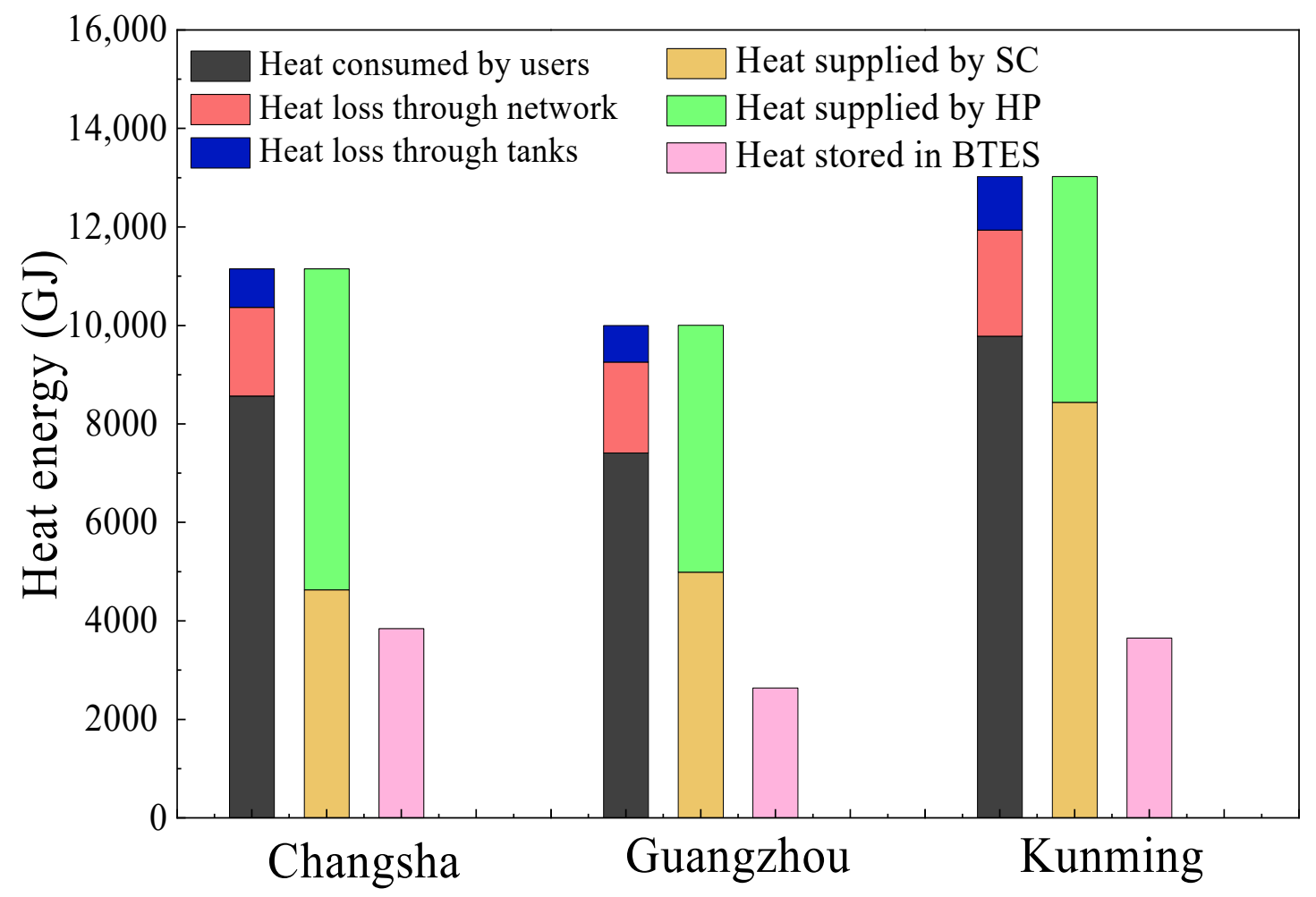

Figure 11. Energy balance of the SAGCHP system during 15 years of operation.

LCC is the cost spent to generate one ton of the DHW using the system over the operating cycle, taking into account equipment costs and production costs. The reason for the highest $L C C_{i n i}$ in Changsha is due to the fact that the largest SC area was selected $\left(338 \mathrm{~m}^{2}\right.$, Table 3$)$. In addition, Figure 11 shows that the SCGCHP system has the most heat supplied by HP and therefore the system has more operating electricity consumption, which causes the highest $L C C_{\text {oper }}$. Therefore, Changsha has the highest cost of producing DHW during 15 years of operation for the three locations. The SCGCHP system in Guangzhou has the lowest SC cost; furthermore, the low solar radiation in summer causes the system to consume less electricity for ground thermal storage. As a result, Guangzhou has the lowest $L C C_{\text {ini }}$ and $L C C_{\text {oper }}$, reaching only $0.720 \mathrm{RMB} /$ ton and $2.478 \mathrm{RMB} /$ ton, respectively; however, the lack of ground thermal storage in summer also leads to an increase in the thermal imbalance problem (the $\Delta T_{B T E S}$ is $-1.6^{\circ} \mathrm{C}$ ).

It is also of interest to analyze the monthly performance of the proposed SAGCHP system. Because BHE requires a "charging" period of several years to reach the design system temperature, the system performance data for the fifth year of operation in Changsha was selected to analyze the monthly performance, and the corresponding results are shown in Figures 12 and 13. 
Table 7. Energetic and economic performance figures for the three locations.

\begin{tabular}{cccccccccc}
\hline Location & $S F$ & $\eta_{B T E S}$ & $S P F_{H P}$ & $S P F_{\text {syst }}$ & $\begin{array}{c}P H L \\
\mathbf{( \% )}\end{array}$ & $\begin{array}{c}\Delta T_{B T E S} \\
\left({ }^{\circ} \mathbf{C}\right)\end{array}$ & $\begin{array}{c}L C C_{\text {ini }} \\
\text { (RMB/ton) }\end{array}$ & $\begin{array}{c}L C C_{\text {oper }} \\
(\mathbf{R M B} / \text { ton) }\end{array}$ & $\begin{array}{c}L C C_{\text {tot }} \\
(\mathbf{R M B} / \text { ton })\end{array}$ \\
\hline Changsha & 0.383 & 1.216 & 2.767 & 2.788 & 22.50 & -0.75 & 0.982 & 2.919 & 3.901 \\
Guangzhou & 0.437 & 1.360 & 2.888 & 3.006 & 25.75 & -1.63 & 0.720 & 2.478 & 3.198 \\
Kunming & 0.680 & 0.597 & 2.697 & 4.764 & 24.95 & 1.35 & 0.883 & 2.485 & 3.368 \\
\hline
\end{tabular}

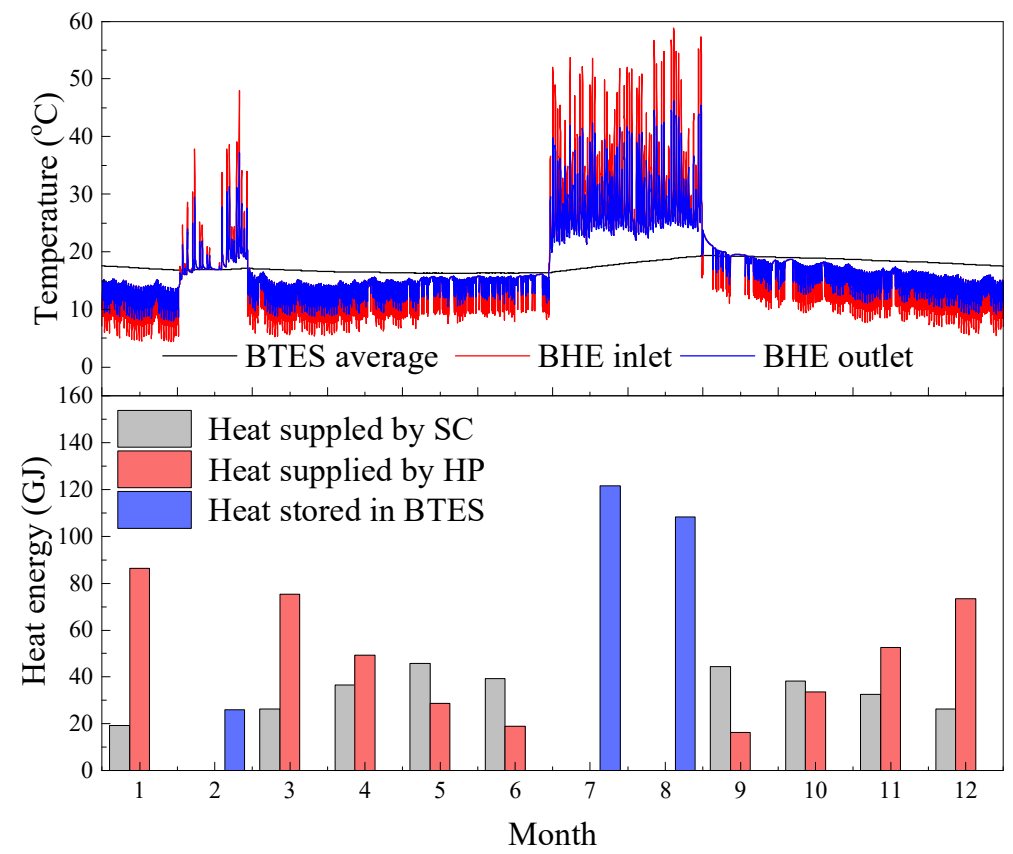

Figure 12. Monthly heat produced and temperature variation of the SAGCHP system with solar seasonal thermal storage in the fifth year.

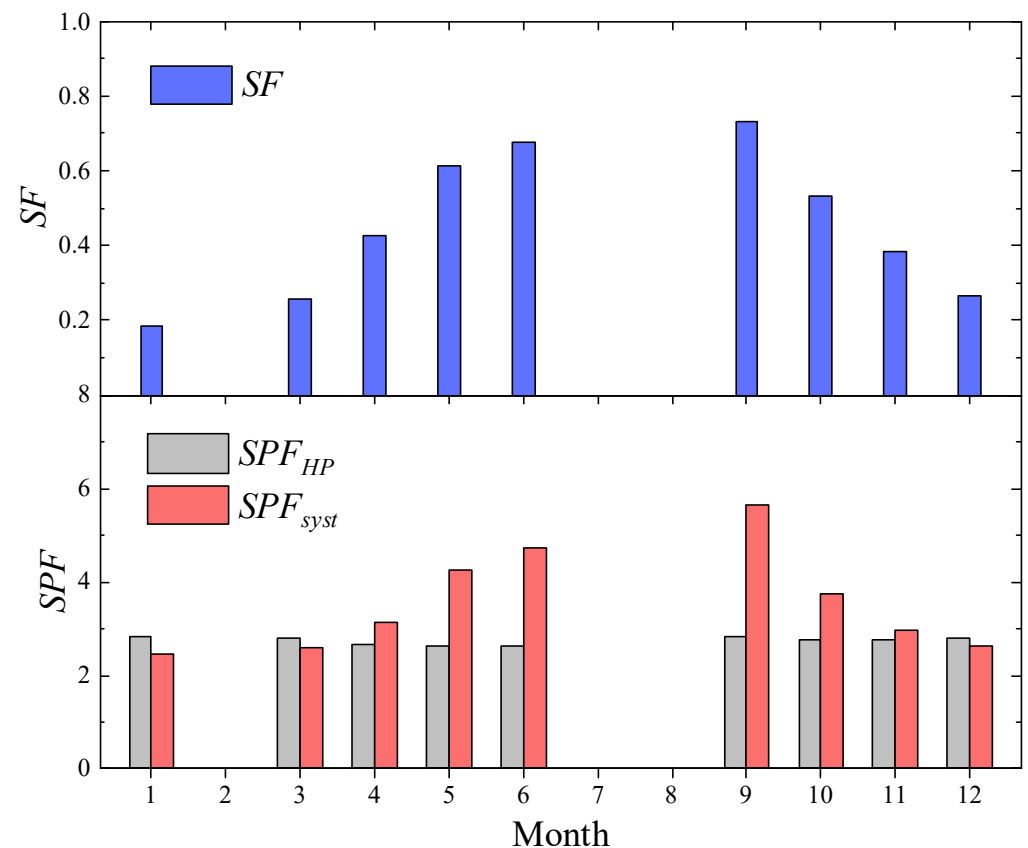

Figure 13. Monthly system performance in the fifth year.

Figure 12 shows that the solar heat injected into BTES during the summer vacation is much higher than that during the winter vacation. With a solar-assisted system, solar 
energy harvested is used for ground recharge during vacations and increasing the source fluid temperature entering the heat pump, and the heat balance of BHE can be improved as well.

Figure 12 also presents the monthly energy balance of the SAGCHP system. It is observed that in winter, the energy is mainly supplied by the heat pumps, while in summer it is mainly supplied by the solar collectors. These results are due to the system control logic, i.e., the heat pumps are programmed to operate only when the energy contribution from the solar collector is not sufficient to meet the demand, which occurs particularly in winter. To analyze the influence of solar heat utilization on the system performance, monthly performance indicators, SF and SPF of the system and the heat pump, are presented in Figure 13. It can be observed that the $S P F_{\text {syst }}$ changes drastically through the whole year, reaching extremely high values of 5.6 near summer due to the high solar contribution. In contrast, during the winter the performance indicator of the system is nearly equal to the $S P F_{H P}$ of the heat pumps.

\subsection{Parametric Analysis}

As discussed in Section 3.2, the size of the solar collector has a large effect on the system performance and is one of the key design parameters of the SAGCHP system. A detailed parametric study was carried out to demonstrate the effect of the solar collector area on the system performance.

In the following simulation, the solar collector areas were changed from $200 \mathrm{~m}^{2}$ to 500 $\mathrm{m}^{2}$, while holding the other design parameters unchanged.

Figure 14 displays the results of different simulated cases. It is obvious from this figure that the solar fraction increases as the solar collector area increases. Meanwhile, as the amount of heat supplied and injected into BTES from solar collection system increases, the ground heat balance can be further improved. When the collector area increases to a certain extent, the long-term underground temperature variation, $\Delta T_{B T E S}$, will even show a positive value, which means that the temperature of the underground soil increases because the heat injected into the BHE is greater than the extracted heat. For the same reason, as the solar collector area increases, the heat storage efficiency, $\eta_{B T E S}$, shows a decreasing trend.

Figure 15 illustrates the influence of solar collector area on the system performance indicators and LCC. As the solar collector area increases, SPF for the whole system and the heat pump are improved, which means that the energy consumption and operation cost can be reduced with the same DHW demand. However, the increase in the collector area also means an increase in the initial cost. When the SC area increases to a certain value, the additional energy saving cannot compensate for the extra initial cost, eventually leading to an increase of the overall cost of the system.

It is obvious from Figure 15 that there exists a minimum $L C C$ that can be reached with a certain value of solar collector area. The optimum collecting area is $260 \mathrm{~m}^{2}, 220 \mathrm{~m}^{2}$ and $320 \mathrm{~m}^{2}$ for Changsha, Guangzhou, and Kunming, respectively. This optimization strategy leads to the selection of a larger collecting area for the location rich in solar resource. It should be noted that although the optimal collector area is different from the design value adopted in the previous simulation section, the variation of $L C C$ among the three locations caused by this difference is not obvious. These LCC curves and the optimal solar collector area are affected by the initial cost of the collector array and electricity prices. Cost-effectiveness analysis based on the local design conditions should be conducted to achieve the optimal design of the SAGCHP system.

According to this analysis, since the solar radiation intensity varies in different regions, the design of the SAGCHP system should consider the selection of solar collector area that matches the local solar radiation intensity, to minimize LCC of the whole system. The SAGCHP system with STES is simulated by TRNSYS software to derive the optimal solar collector area, which is beneficial for the economic operation of the SAGCHP system. 


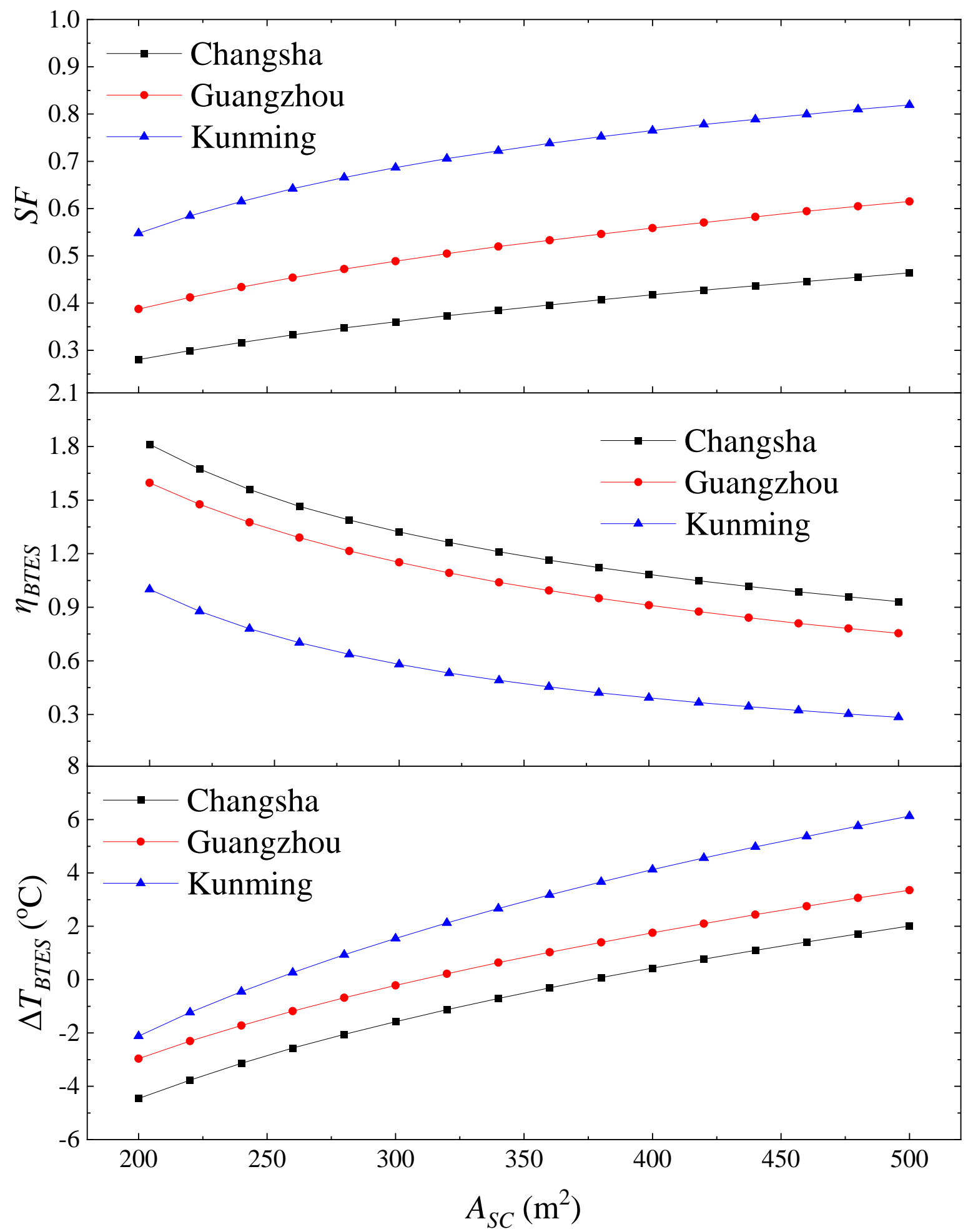

Figure 14. Values of $S F, \eta_{B T E S}$ and $\triangle T_{B T E S}$ as a function of $A_{S C}$. 


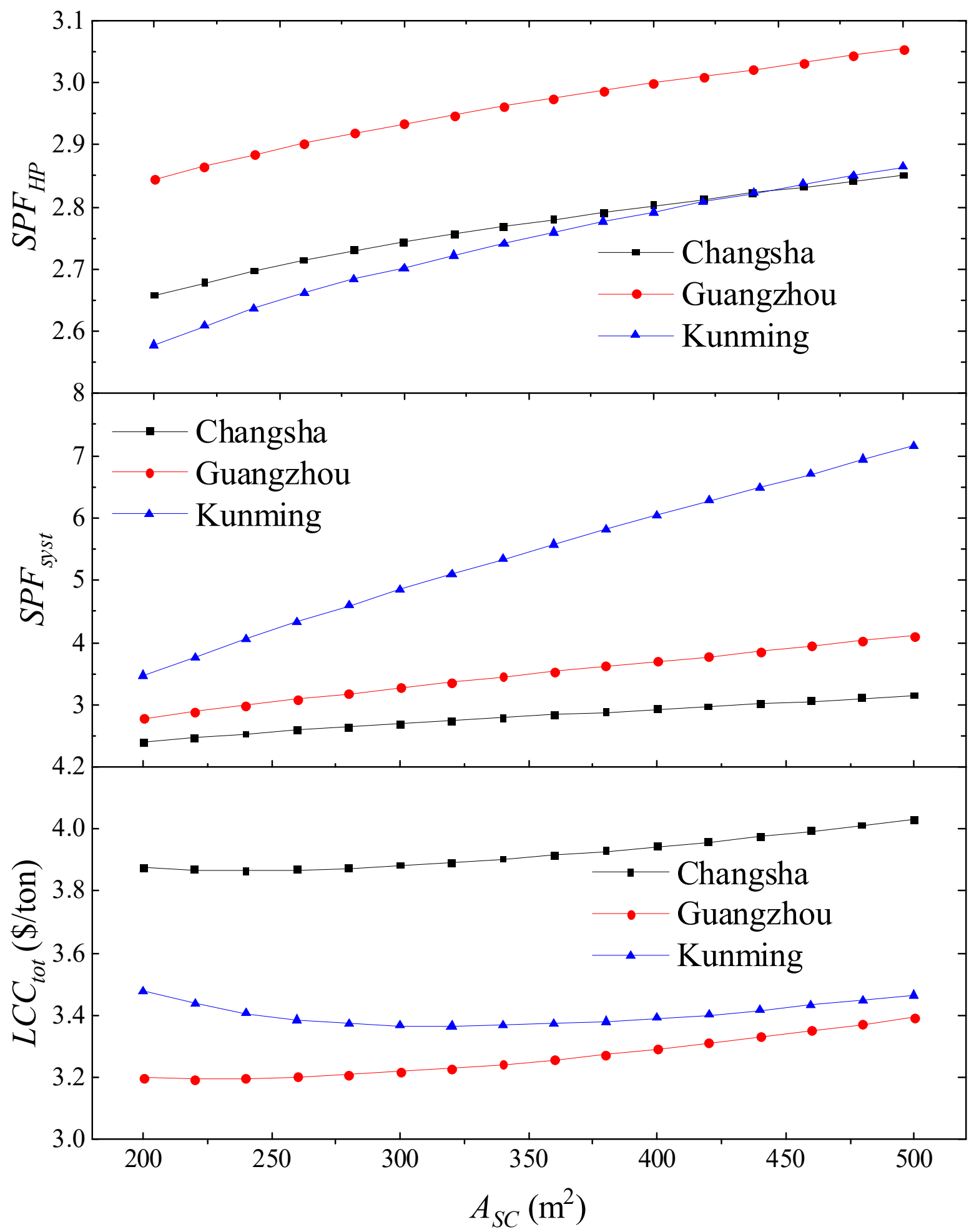

Figure 15. Values of $S P F_{H P}, S P F_{\text {syst }}$ and $L C C_{\text {tot }}$ as a function of $A_{S C}$.

\section{Conclusions}

In this paper, a SAGCHP using seasonal BTES was analyzed by means of dynamic simulations over a 15-year period. The system was investigated by assuming that it serves the DHW demand of 960 students for a Chinese college dormitory building under the climatic conditions of Changsha, Guangzhou and Kunming (three typical cities of southern China). The underground heat balance of the proposed system was first analyzed and 
compared energetically with the system without BTES and the standalone GCHP DHW system. The analyses of the energy and financial performances, in terms of solar fraction, seasonal performance factor, borehole storage efficiency, heat loss, a variation of average ground temperature, and LCC, were then carried out for the three selected locations. Finally, a sensitivity analysis was undertaken for the three locations by varying the solar collector area, which was regarded as the most important influencing factor. The following conclusions can be drawn:

- Compared to the system without BTES and standalone GCHP DHW system, the SAGCHP DHW system can alleviate the thermal imbalance caused by the continuous heat extraction from the ground, and correspondingly can improve the system performance. When this system was applied to areas with abundant solar energy resources (such as Kunming in this research), the average temperature of the soil may even increase slightly year by year because the stored heat is much larger than the extracted heat.

- The proposed system reaches the system seasonal performance factor $\left(S P F_{s y s t}\right)$ of 2.788, 3.006 and 4.764 for Changsha, Guangzhou and Kunming, respectively. The differences can be attributed to the diversity of solar energy resource among the different locations. However, the values of $S P F_{h p}$ for the three locations are remarkably close. It is also found that for areas with abundant solar energy resources, such as Kunming, the solar energy utilization rate of the system and the corresponding SF are much higher than those in Changsha and Guangzhou, which is the main reason for the significant improved $S P F_{\text {syst }}$.

- $\quad$ For the proposed SAGCHP system, although the heat storage operation is performed both in the winter and summer vacation, the amount of solar thermal energy storage and the corresponding soil temperature recovery during the summer vacation is much higher than that in the winter vacation.

- Increasing the solar collector area means an increase in the amount of solar energy. This fact not only causes an increase in the $S F$, but also allows more heat to be injected and stored underground, which further improves the underground heat balance. When the solar collector area increases to a certain extent, the soil temperature will rise with yearly fluctuations.

- The increase of the solar collector area increases the initial investment but reduces the energy consumption of the heat pump unit and the corresponding operating cost. Therefore, there exists an optimal solar collector area to achieve the lowest system LCC. It should be noted that the optimal value of the collector area is different from the design value in the previous section. The difference of LCC among the three locations caused by the different optimal solar collector area, however, is not obvious, and the optimal collector area is affected by the cost of the collector and electricity prices.

- In the practical engineering application of SAGCHP systems, the amount of ground imbalance heat of the SAGCHP system with STES can be simulated using TRNSYS software to get a clear perspective of the system dynamics. Based on the in-depth system characterization, the optimal solar collector area can be obtained according to the local solar radiation intensity, providing a systematic instruction for design and economic operation of the SAGCHP system.

Author Contributions: Conceptualization, J.Z. and F.X.; funding acquisition, F.X.; methodology, J.Z. and Z.C.; software, Z.C.; validation, J.Z. and Z.C.; formal analysis, J.Z.; resources, G.Z.; writingoriginal draft preparation, J.Z. All authors have read and agreed to the published version of the manuscript.

Funding: This research was funded by National Key R\&D Program of China (grant number 2019YFD1101300) and Hunan Province In-novation Development Program (grant number 2020RC4045 and 2020TP1009).

Institutional Review Board Statement: Not applicable. 
Informed Consent Statement: Not applicable.

Data Availability Statement: The data presented in this study are available on request from the corresponding author. The data are not publicly available due to privacy.

Conflicts of Interest: The authors declare no conflict of interest.

\section{References}

1. International Energy Agency. Technology Roadmap—Solar Heating and Cooling, 2012. Available online: https://www.iea.org/ reports/technology-roadmap-solar-heating-and-cooling (accessed on 5 April 2021).

2. State Council, Authorities Urged All Academic Institutions to Develop Resource Efficient Campuses. Available online: http: / / www.gov.cn/jrzg/2012-06/16/content_2162487.htm (accessed on 5 April 2021). (In Chinese)

3. Yuan, X.; Zuo, J.; Huisingh, D. Green Universities in China-What matters? J. Clean. Prod. 2013, 61, 36-45. [CrossRef]

4. Ministry of Education, Bulletin of National Education Statistics 2017. Available online: http://www.moe.gov.cn/jyb_sjzl/sjzl_ fztigb / (accessed on 5 April 2021). (In Chinese)

5. Hu, X.A. The Research on Evaluation Index and the Energy Consumption Analysis of a University in Zhejiang Province. Master's Thesis, Zhejiang University, Hangzhou, China, 2014. (In Chinese).

6. Yang, Y. Establishment and Application of Evaluation Index System in a University in Anhui Province. Master's Thesis, Anhui Jianzhu University, Hefei, China, 2016. (In Chinese).

7. Tan, H.W.; Xu, Y.L.; Hu, C.Y.; Liu, Y. Research on building campus energy management. Build. Energy Environ. 2010, 29, 36-40. (In Chinese)

8. Wright, T.S.A. Definitions and frameworks for environmental sustainability in higher education. High. Educ. Policy 2002, 15, 105-120. [CrossRef]

9. Xu, J.; Wang, R.Z.; Li, Y. A review of available technologies for seasonal thermal energy storage. Sol. Energy 2014, 103, 610-638. [CrossRef]

10. He, J.; Liu, H.J.; Luo, Y.W. A study on integration design of solar hot-water systems in high-rise residential buildings. Appl. Mech. Mater. 2014, 507, 501-504. [CrossRef]

11. Rad, F.; Rad, M.; Fung, A.S. Solar community heating and cooling system with borehole thermal energy storage-Review of systems. Renew. Sustain. Energy Rev. 2016, 60, 1550-1561. [CrossRef]

12. Khoshbakht, M.; Gou, Z.H.; Dupre, K. Energy use characteristics and benchmarking for higher education buildings. Energy Build. 2018, 164, 61-76. [CrossRef]

13. Chen, X.; Lu, L.; Yang, H.X. Long term operation of a solar assisted ground coupled heat pump system for space heating and domestic hot water. Energy Build. 2011, 43, 1835-1844.

14. Trillat-Berdal, V.; Souyri, B.; Achard, G. Coupling of geothermal heat pumps with thermal solar collectors. Appl. Therm. Eng. 2007, 27, 1750-1755. [CrossRef]

15. Rad, F.M.; Fung, A.S.; Leong, W.H. Feasibility of combined solar thermal and ground-source heat pump systems in cold climate, Canada. Energy Build. 2013, 61, 224-232. [CrossRef]

16. Zhao, J.; Chen, Y.; Lu, S.Z.; Cui, J. Optimization of serial combined system of ground-coupled heat pump and solar collector. Trans. Tianjin Univ. 2009, 15, 37-42. (In Chinese) [CrossRef]

17. Wang, F.; Zheng, M.Y.; Shao, J.P.; Li, Z.J. Simulation of embedded heat exchangers of solar aided ground source heat pump system. J. Cent. South. Univ. Technol. 2008, 15, 261-266. [CrossRef]

18. Zhai, X.Q.; Qu, M.; Yu, X.; Yang, Y.; Wang, R. A review for the applications and integrated approaches of ground-coupled heat pump systems. Renew. Sust. Energy Rev. 2011, 15, 3133-3140. [CrossRef]

19. Wang, X.; Zheng, M.Y.; Zhang, W.Y.; Zhang, S.; Yang, T. Experimental study of a solar assisted ground-coupled heat pump system with solar seasonal thermal storage in severe cold areas. Energy Build. 2010, 42, 2104-2110. [CrossRef]

20. Xu, L.Y.; Torrens, J.I.; Guo, F.; Yang, X.; Hensen, J. Application of large underground seasonal thermal energy storage in district heating system: A model-based energy performance assessment of a pilot system in Chifeng, China. Appl. Therm. Eng. 2018, 137, 319-328. [CrossRef]

21. An, J.J.; Yan, D.; Deng, G.W.; Yu, R. Survey and performance analysis of centralized domestic hot water system in China. Energy Build. 2016, 133, 321-334. [CrossRef]

22. Yin, X.P. Research on the Behavior Characterization and Simulation of Domestic Hot Water Utilization of College Students. Master's Thesis, Hunan University, Changsha, China, 2017. (In Chinese).

23. Zhou, J.; Yin, X.P.; Yin, S.F.; Wang, Z.R.; Xu, F. Research on the behavior characterization of domestic hot water utilization of college students. Water Wastewater Eng. 2017, 43, 91-95. (In Chinese)

24. The Ministry of Housing and Urban-Rural Development of the People's Republic of China. Code for Design of Building Water Supply and Drainage, GB 50015-2019; China Planning Press: Beijing, China, 2003. (In Chinese)

25. China Nuclear Power Engineering Co. Handbook for Design of Building Water Supply and Drainage, Volume 2: Building Water Supply and Drainage, 3rd ed.; China Architecture \& Building Press: Beijing, China, 2012. (In Chinese)

26. TRNSYS, The Transient Energy System Simulation Tool. Available online: http:/ /www.trnsys.com (accessed on 5 April 2021).

27. Duffie, J.A.; Beckman, W.A. Solar Engineering of Thermal Processes, 4th ed.; John Wiley \& Sons, Inc.: New York, NY, USA, 2013. 
28. China Institute of Building Standard Design \& Research. Solar Heat Collecting System-Design and Installation (06K503); China Planning Press: Beijing, China, 2006. (In Chinese)

29. Flynn, C.; Sirén, K. Influence of location and design on the performance of a solar district heating system equipped with borehole seasonal storage. Renew. Energy 2015, 81, 377-388. [CrossRef]

30. Ciampi, G.; Rosato, A.; Sibilio, S. Thermo-economic sensitivity analysis by dynamic simulations of a small Italian solar district heating system with a seasonal borehole thermal energy storage. Energy 2018, 143, 757-771. [CrossRef]

31. DAIKIN, Catalog 1107-6, Daikin Water to Water Source Heat Pumps, Models WRA, WHA and WCA, Unit Sizes 036-420 R410A Refrigerant. Available online: https://daikin.com.mx/wp-content/uploads/2017/01/Cat_1107-6_WS_Wtr2Wtr_WRA-WHAWCA_36-420LR.pdf (accessed on 5 April 2021).

32. Philippe, M.; Marchio, D.; Hagspiel, S.; Riederer, P.; Partenay, V. Analysis of 30 underground thermal energy storage systems for building heating and cooling and district heating. In Proceedings of the 11th International Conference on Thermal Energy Storage: Thermal Energy Storage for Efficiency and Sustainability, Stockholm, Sweden, 14-17 June 2009.

33. Sibbitt, B.; Mcclenahan, D.; Djebbar, R.; Thornton, J.; Wong, B.; Carriere, J.; Kokko, J. Measured and simulated performance of a high solar fraction district heating system with seasonal storage. In Proceedings of the 30th ISES Biennial Solar World Congress, Kassel, Germany, 28 August-2 September 2011.

34. Schulte, D.O.; Rühaak, W.; Oladyshkin, S.; Welsch, B.; Sass, I. Optimization of medium-deep borehole thermal energy storage systems. Energy Technol-Ger. 2016, 4, 104-113. [CrossRef] 